\title{
Production of nitrogen rich ingredients from fish waste by a biotechnological process
}

\author{
M Faid, A Zouiten, A Elmarrakchi \\ IAV Hassan II, BP 6202, Rabat-Instituts, Morocco
}

A severe shortness in nitrogen rich resources in the field of animal feeding is being felt in developing countries and the need is increasing more and more in countries where the animal production is being improved. However, some nitrogen resources are still not valorized or unknown. Fish waste may represent an important source of nitrogen to be deeply studied. Only part of fish wastes are dried, the remaining is thrown. Fish-meal use is restricted by the fish-odor and the high cost of the production. Silage techniques applied to fish waste were investigated by several workers in the Scandinavian countries. The investigators showed various aspects of fish silage in different diets (Raa and Gildberg, 1982, Crit Rev Food Sci Nutr, 16, 383-419 ; Espe et al, 1992, J Sci Fd Agric, 58, 315-319). So far, the fish silage is still not known to the Moroccan industrials and/or farmers despite the severe lack of animal feed ingredients.

Biotransformation of fish waste by biotechnological procedures for the production of nitrogen rich ingredients to be used in feeds may open new views in this field. When the conditions are well monitored, a chemical composition of the product is accurately known and the use in the right formula is easy to define. This can be for ruminants, small ruminants, chickens and/or other animals.

Fish wastes were minced, supplied with $15 \%$ molasses and inoculated with a starter culture made of Lacobacillus plantarum and Pediococcus sp. The mixture was incubated at room temperature $\left(20-22^{\circ} \mathrm{C}\right)$. Chemical and physico-chemical determinations included $\mathrm{pH}$, dry matter (DM), ash, fat, reducing sugars (RS), total nitrogen (TN), non protein nitrogen (NPN), total volatile nitrogen (TVN) and microbiological determinations including Enterobactereaceae, lipolytics, proteolytics, yeasts and lactic acid bacteria were followed up during 15 days. Results indicated that the $\mathrm{pH}$ decreased slowly and remained constant at 4.04. The TN decreased while the NPN and TVN increased significantly. The trimethylamine (TMA) decreased or remained constant at low levels. The microbiological characteristics showed a rapid decreased to reach low levels after 2 days. Lipolytics and proteolytics decreased notably during fermentation and reached a minimum of less than $1 \mathrm{cfu} / \mathrm{g}$.

The obtained product had the following chemical composition :

\begin{tabular}{cccccccccc}
$\mathrm{pH}$ & $\begin{array}{c}\mathrm{DM} \\
(\%)\end{array}$ & $\begin{array}{c}\text { Ash } \\
(\% \mathrm{DM})\end{array}$ & $\begin{array}{c}\text { Fat } \\
(\%)\end{array}$ & $\begin{array}{c}\text { RS } \\
(\%)\end{array}$ & $\begin{array}{c}\text { Proteins } \\
(\%)\end{array}$ & $\begin{array}{c}\mathrm{TN} \\
(\% \mathrm{DM})\end{array}$ & $\begin{array}{c}\mathrm{NPN} \\
(\% \mathrm{TN})\end{array}$ & $\begin{array}{c}\text { TVN } \\
(\mathrm{mg} / \mathrm{g} \mathrm{DM})\end{array}$ & $\begin{array}{c}\mathrm{TMA} \\
(\mathrm{mg} / \mathrm{g} \mathrm{DM})\end{array}$ \\
\hdashline 4.03 & 34.63 & 7.76 & 5.9 & 12.9 & 9.8 & 1.56 & 54.2 & 2.35 & 0.04
\end{tabular}

